\title{
PENDIDIKAN HUKUM MASYARAKAT MELALUI KINERJA KOMISI PEMBERANTASAN KORUPSI
}

\author{
Usman Alhudawi ${ }^{1 *}$, Ismi Sujastika ${ }^{2}$ \\ ${ }^{1) 2)}$ Universitas Pendidikan Indonesia, Jawa Barat, Indonesia \\ *usmanalhudawi@upi.edu
}

\begin{abstract}
The Corruption Eradication Commission (KPK) in addition to law enforcement agencies in the scope of corruption, also has a role to carry out anti-corruption education through legal education. The implementation of legal education is carried out in educational institutions and the community. This article describes the specifics of public legal education by the KPK through the KPK's performance from various literary sources. The research method used is qualitative. This research was conducted with a literature study with qualitative data collection techniques in the form of literature study (literature). Meanwhile, the data analysis process used is data reduction, data display, verification and conclusion drawing. The results show that the performance of legal education is given to students and the public. Due to the generality nature of legal education by the KPK, it becomes a role model for legal certainty in the community. This can be seen when the KPK has conveyed its wide-ranging performance in various mass media to provide meaning and experience in monitoring the implementation of national law by the public.
\end{abstract}

Keywords: legal education, legal understanding, legal awareness, KPK performance

\begin{abstract}
Abstrak
Komisi Pemberantasan Korupsi (KPK) selain lembaga penegak hukum pada ruang lingkup tindak pidana korupsi, juga memiliki peran untuk melakukan pendidikan anti korupsi melalui pendidikan hukum. Pelaksanaan pendidikan hukum dilakukan di lembaga pendidikan dan dimasyarakat. Artikel ini membentangkan secara spesifik pendidikan hukum masyarakat oleh KPK melalui kinerja KPK dari berbagai sumber literatur. Metode penelitian yang digunakan adalah kualitatif. Penelitian ini dilakukan dengan studi literatur dengan teknik pengumpulan data kualitatif berupa studi pustaka (literatur). Sementara itu, proses analisis data yang digunakan adalan reduksi data, display data, verifikasi dan penarikan kesimpulan. Hasil menunjukan bahwa kinerja pendidikan hukum diberikan untuk kalangan pelajar dan mahasiswa serta masyarakat. Karena sifat keumuman Pendidikan hukum oleh KPK menjadi role model kepastian hukum masyarakat. Hal tersebut tampak tatkalah KPK menyampaikan kinerjanya luas diberbagai media massa sehingga memberi makna dan pengalaman memantau pelaksanaan hukum nasional oleh masyarakat.
\end{abstract}

Kata kunci: KPK, pendidikan hukum, dan kinerja KPK 


\section{PENDAHULUAN}

Ketika mendiskusikan kesadaran hukum pada masyarakat maka perlu memperhatikan aspek penegakan hukum. Hal ini disebabkan masyarakat secara umum melihat hukum dari sisi pemberlakuan dan penegakan yang ada di sekitarnya, terutama dalam lingkup nasional. Dalam Saifullah (2007, hal. 105), dijelaskan bahwa telaah yang pernah dilakukan oleh Soerjono Soekanto tentang kesadaran dan kepatuhan hukum di tahun 1982 membuka pintu kajian semakin jelas akan pentingnya ketertiban masyarakat dalam mematuhi secara sadar konsepsi hukum yang telah disahkan dan dilaksanakan dengan konsekuen dalam komunikasi dan hubungan masyarakat, berbangsa dan bernegara bahkan berpolitik. Dengan kata lain, kepatuhan terhadap konsepsi hukum yang ada ini tidak bisa serta merta terbentuk dalam masyarakat. Perlu berbagai usaha yang dilakukan. Usaha ini secara umum bisa disebut sebagai pendidikan kewarganegaraan

Wahab \& Sapriya (2011, hal. 311) menerangkan bahwa tujuan Pendidikan Kewarganegaraan adalah membentuk warga negara menjadi warga negara yang baik (to be good citizen). Senada dengan kajian tersebut, fokus Pendidikan Kewarganegaraan adalah proses untuk membentuk kesadaran hukum di dalam masyarakat/warga negara. Selanjutnya, untuk dapat digolongkan dalam warga negara baik, maka masyarakat harus memiliki pemahaman dan kesadaran yang sah dan berlaku. Maka pendidikan hukum adalah hal lazim dalam negara yang menjunjung tinggi asas sebagai negara hukum. Lebih lanjut Nasution (2016, hal. 201) menjelaskan tujuan pendidikan kewarganegaraan pada dasarnya adalah menjadikan warga negara yang cerdas dan baik serta mampu mendukung keberlangsungan bangsa dan negara. Upaya mewarganegarakan individu atau orang orang yang hidup dalam suatu negara menjadi tugas dan tanggung jawab pokok yang diemban oleh Negara.

Membangun pendidikan hukum pada masyarakat memiliki titik tekan yang berbeda dengan pendidikan hukum di sekolah tinggi hukum maupun fakultas hukum. Pendidikan hukum pada masyarakat berorientasi terhadap kepatuhan hukum itu sendiri, yang mana hal ini dikemukakan dalam Saifullah (2007, hal. 105) bahwa munculnya kesadaran hukum didorong oleh sejauh mana kepatuhan kepada hukum yang didasari oleh: indoctrination, habituation, utiliy, dan group identification. Ahmad (2018, hal. 16) menyatakan bahwa kepatuhan hukum juga merupakan suatu proses psikologis yang bersifat kualitatif dan didasari oleh tiga hal, yakni compliance (kerelaan), identification (pengenalan), dan internalization (internalisasi).

Proses kesadaran tersebut diamati dan dipelajari secara langsung oleh masyarakat melalui penegakan hukum oleh lembaga-lembaga hukum Negara. Namun hal ini di anggap tidak efektif terhadap peningkatan pendidikan hukum di Indonesia, disebabkan tingkat kepercayaan masyarakat terhadap lembaga hukum yang rendah. Dalam Saifullah (2007, hal. 106), kondisi keterpurukan hukum di Indonesia yang telah membusuk ini membawa banyak konsekuensi moral utamanya kepada para pemikir maupun praktisi hukum dalam menyikapi berbagai tudingan yang akhirnya bermuara pada runtuhnya kepercayaan masyarakat terhadap hukum.

Survey menunjukkan adanya perubahan tingkat kepercayaan masyarakat yang tinggi sejak dibentuknya lembaga Komisi Pemberantasan Korupsi (KPK). Lembaga KPK seolah-olah membawa angin segar bagi sistem penegakan hukum, dan yang lebih penting yaitu meningkatnya antusias masyarakat untuk mengikuti dan mempelajari kasus-kasus 
hukum yang menjerat pada koruptor. Hal inilah yang akhirnya menjadikan Lembaga KPK sebagai lembaga hukum yang memiliki peran penting dalam pelaksanaan pendidikan hukum di masyarakat.

\section{METODE PENELITIAN}

Penelitan ini menggunakan pendekatan kualitatif yang artinya, pengumpulan data dilakukan dengan cara mengumpulkan data dari sumber pertama, sumber bahan cetak kepustakaan, meliputi buku, jurnal, makalah dan literatur lain yang relevan dengan kajian artikel ini. Langkah selanjutnya adalah melakukan kajian yang berkaitan dengan teori, dan sumber penelitian yang relevan. Adapun sumber-sumber pustaka sebagai data pembanding dapat diperoleh dari buku, jurnal, majalah, hasil-hasil penelitian (tesis dan disertasi), dan sumber lainnya yang sesuai.

\section{HASIL DAN PEMBAHASAN}

\section{Pendidikan Kesadaran Hukum}

Wignjosoebroto (2013, hal. 102) membincangkan tentang kesadaran hukum, yang di dalam kepustakaan berbahasa Indonesia disebut dengan 'legal awareness' dalam gatra kognitif mengacu pada pengetahuan seseorang tentang ada tidaknya aturan yang mengatur perbuatan yang sedang dilakukan atau tengah menjadi perhatiannya yang utama. Sementara dalam gatra afektifnya, merujuk pada pelibatan dirinya secara emosional ke suatu pihak tertentu berdasarkan keyakinan bahwa apa yang diketahui merupakan sesuatu yang benar, oleh sebab itu sudah seharusnya untuk dituruti dan dipatuhi. Subiharta (2015, hal. 393) menyampaikan bahwa kesadaran hukum masyarakat juga dipengaruhi oleh kehidupan sosial dimana masyarakat itu berada.

Dalam masyarakat modern, salah satu cara untuk mengetahui pengaruh jangkauan hukum dalam masyarakat, terlebih dahulu harus diurai kesalahan konsep mengenai hukum yang popular di tengah masyarakat yaitu "hukum hanya mengatur masalah kejahatan saja". Karena sejatinya, hukum tak hanya mengatur masalah kejahatan, tetapi banyak hal penting lain yang dikaji di dalamnya, misalnya filsafat hukum, norma hukum, maupun ilmu hukum itu sendiri. Tentu saja kesalahan konsep yang terlanjur dipahami oleh masyarakat diakibatkan oleh konsepsi hukum yang terpelihara dengan adanya pemberitaan di media masa.

Hukum secara umum memiliki cabang-cabang konsep yang sangat banyak, oleh karena itu jika dipahami secara parsial akan rentan melahirkan pemahaman yang tidak tepat mengenai hukum itu sendiri. Oleh karena itu, seluruh anggota masyarakat diharuskan memiliki kesadaran hukum yang baik guna melahirkan pemahaman hukum yang utuh. Soekanto (1982, hal. 152), menjelaskan bahwa kesadaran hukum merupakan kesadaran akan nilai-nilai yang terdapat dalam diri manusia tentang hukum yang ada atau yang diharapkan ada. Sebenarnya penekanan di sini terdapat dalam nilai-nilai fungsi hukum dan bukan suatu penilaian hukum terhadap kejadian-kejadian yang konkrit dalam masyarakat yang bersangkutan. Hal tersebut menunjukan hukum selalu mengarah kepada masalah bagaimana kedudukan dan peranan hukum sebagai lembaga yang bekerja dalam 
masyarakat. Pendidikan hukum adalah penghubung yang membentuk masyarakat memiliki pemahaman hukum dan yang terpenting adalah memiliki kesadaran hukum.

Berbicara tentang kepatuhan atau ketaatan masyarakat pada hukum, Tauratiya (2018, hal. 64) menyebutkan bahwa hal ini didasarkan pada tingkat kesadaran hukum yang dimiliki oleh seseorang terhadap hukum yang ada dan berlaku saat ini (ius constitutum), maupun pada hukum yang diharapkan akan ada atau yang dicita-citakan di masa yang akan dating (ius constituendum). Dalam Erwin (2011, hal. 135) "kesadaran hukum pada hakikatnya merupakan kesadaran tentang diri kita sendiri, dimana seseorang melihat dan berhadapan dengan hukum. Orang yang memiliki kesadaran hukum berarti ia yakin akan cita-cita kebaikan yang setinggi-tingginya". Dari ini kita dapat melihat bahwa penanaman kesadaran hukum dalam masyarakat sangat penting dalam tatanan negara. Hal itu menjadi dasar untuk lebih menguatkan pendidikan hukum, sosialiasi hukum dan memasyarakatkan nilai hukum sehingga prinsip-prinsip keadilan menjadi menjadi konsumsi dan nilai hidup seluruh warga negara.

Argumentasi konsep di atas merupakan pandangan hukum sebagai sesuatu yang tumbuh secara alamiah dalam pergaulan masyarakat itu sendiri. Teori ini menjadi penting, ketika dihadapkan pada kajian tentang pembangunan suatu negara. Pembangunan yang dimaksud tentu saja bukan perubahan yang bersifat parsial. Bukan pula perubahan yang bersifat kuantitatif, akan tetapi perubahan menyeluruh dan bernilai (kualitatif), meskipun hukum bukanlah satu-satunya indikator yang memegang peranan penting dalam pembangunan. Menurut Asshiddiqie (dalam Purba, 2017, hal. 149) bahwa pembudayaan, pemasyarakatan dan pendidikan hukum (law socialization and law education) dalam arti luas sering tidak dianggap penting, padahal tanpa didukung oleh kesadaran, pengetahuan dan pemahaman oleh para subjek hukum dalam masyarakat, akan sangat sulit suatu norma hukum dapat diterapkan tegak dan ditaati.

Dari sudut pandang lain dinyatakan bahwa pentingnya pendidikan hukum dakam masyarakat juga disebabkan oleh adanya kenyataan bahwa segala aspek kehidupan bernegara diatur dan tunduk pada peraturan sistem hukum yang berlaku, dimana hal tersebut melahirkan konsekuensi bagi Negara untuk membentuk masyarakat yang memiliki kesiapan, memahami, dan menyadarkan pada norma-norma yang timbulkan dari sistem hukum yang berlaku. Meski pada kenyataannya, Sarana formal dalam pendidikan hukum belum dapat memberikan dampak yang masif dalam menciptakan kesadaran hukum kepada seluruh lapisan warga negara. Oleh karena itu diperlukan metode alternatif sebagai sarana pendidikan hukum yang lebih kreatif, dekat dengan masyarakat dan sesuai dengan kebutuhan hukum masyarakat.

\section{Kesadaran Hukum}

Sangat lazim bahwa setiap Negara hukum akan menerapkan peraturan yang dianggap sesuai untuk mengatur kehidupan yang berlaku dalam masyarakat. Meski demikian, bukan tidak mungkin jika peraturan yang ada justru menimbulkan perdebatan atau pengabaian yang disebabkan ketidakpahaman terhadap esensi hukum. Oleh karena itu, penting sekali bagi pengamat untuk memahami perilaku kesadaran hukum yang berkaitan langsung dengan kepatuhan hukum.

Soekanto (1977, hal. 462) menyatakan bahwa kesadaran hukum (non spiritual) dalam masyarakat dibentuk oleh kalangan atau lembaga hukum. Artinya persepsi tentang hukum dibangun oleh lembaga hukum dengan cara bagaimana hukum itu

\section{JURNAL KEWARGANEGARAAN}


dikomunikasikan. Dengan adanya komunikasi hukum yang baik maka akan timbul beberapa dampak, diantaranya munculnya pengetahuan hukum dalam masyarakat, nalar yang timbul sebagai respon setelah memiliki pengetahuan hukum itu sendiri, dan yang terakhir adalah sikap sebagai representasi terhadap pengetahuan dan nalar yang dimiliki. Sikap inilah yang menjadi titik tolak seseorang disebut dengan patuh terhadap hukum atau sebaliknya.

Dalam pendapat lain Suparman (2016, hal. 185) menjelasksan bahwa kesadaran hukum akan terbangun apabila terdapat budaya hukum dalam masyarakat. Artinya antara budaya hukum dan kesadaran hukum merupakan dua hal yang tidak dapat dipisahkan. Usman (2014, hal. 29-30) menyatakan bahwa kesadaran hukum merupakan perasaan dan keyakinan hukum yang mengikat dalam diri seseorang. Perasaan dan keyakinan hukum inilah yang harus dibangun dalam diri masyarakat baik secara langsung maupun tidak langsung. Membangun kesadaran hukum secara langsung dilakukan dengan cara pendidikan hukum, sementara yang tidak langsung dilakukan dengan memberikan informasi hukum melalui berbagai media. Maka dalam hal ini, membangun kesadaran hukum secara langsung sangat bergantung kepada peran media social dalam menyampaikan informasi. Maka tidak berlebihan kiranya jika disimpulkan bahwa peran media sosial sangat mempengaruhi kesadaran hukum masyarakat.

Kesadaran hukum sangat berkaitan dengan aspek kognitif dan perasaan. Kedua hal ini dianggap sebagai penghubung antara hukum dengan pola perilaku masyarakat. Aspek kognitif menyerap hal-hal yang secara logis bisa diterima oleh akal pikiran. Utamanya hukum, maka hukum akan mudah terserap dan terinternalisasi manakala sesuai dengan akal pikiran manusia. Singkatnya, kesadaran hukum menjadi faktor penentu internalisasi hukum pada pola perilaku masyarakat. Internalisasi ini bertujuan untuk menjadikan hukum merasuk dalam aktifitas masyarakat. Sementara perasaan berperan sebagai pemberi keputusan hukum yang sesuai dengan norma yang berlaku, tentang pantas atau tidak pantas, serta keputusan tentang timbulnya semangat menegakkan hukum yang ada.

Pada umumnya kesadaran hukum dikaitkan dengan ketaatan hukum atau efektivitas hukum yang berlaku dalam masyarakat. Kesadaran hukum menyangkut apakah ketentuan hukum tertentu benar-benar berfungsi atau tidak dalam masyarakat. Masyarakat melihat dan menilai secara langsung bagaimana penegakan hukum oleh pemegang kekuasaan, menakar melalui takaran nilai yang diyakini, dan akhirnya memberikan interpretasi hukum yang disebut dengan kepatuhan hukum. Seseorang dikatakan memiliki kesadaran hukum jika mencapai indikator pencapaian yang ditetapkan. Misalnya, menurut Soekanto (1977, hal. 464) bahwa seseorang dikatakan memiliki kesadaran hukum jika mampu memahami materi hukum, isi hukum, mampu menelaah dengan pikiran dan mengaplikasikan dalam kehidupan sehari-hari. Sebagaimana dituliskan dalam Abdullah (2015, hal. 193) bahwa kesadaran hukum dimulai dari anggapan bahwa hukum tersebut sesuai dengan kesadarannya. Kesadaran hukum lahir dari kemampuan seseorang memaknai logika hukum yang tersirat dalam sebuah peraturan. Hal ini sedikit berbeda dengan pernyataan Salman (1993, hal. 40-42) yang menjelaskan bahwa seseorang dikatakan memiliki kesadaran huku jika memiliki indikator antara lain yang pertama adanya pengetahuan tentang hukum, dimana seseorang mengetahui suatu perilaku tertentu telah diatur oleh hukum. Peraturan hukum yang dimaksud disini adalah hukum tertulis maupun hukukum yang tidak tertulis, perilaku tersebut menyangkut perilaku yang dilarang oleh hukum maupun perilaku yang diperbolehkan oleh hukum. 
Indikator yang kedua yaitu pemahaman utuh hukum itu sendiri, yaitu informasi yang dimiliki seseorang tentang isi peraturan hukum tertentu. Pemahaman hukum di sini merupakan keutuhan pemahaman terhadap isi dan tujuan sebuah peraturan hukum tertentu serta manfaatnya bagi pihak yang berkenaan dalam kehidupannya. Misalnya adanya pengetahuan dan pemahaman yang benar mengenai Perda No 7 Tahun 2012 tentang penyelenggaraan ketertiban umum. Khususnya tentang pedagang kaki lima untuk mewujudkan kesadaran dan paham akan hukum tersebut. Selanjutnya Indikator yang ketiga adalah sikap hukum, yaitu kecenderungan untuk menerima hukum karena adanya penghargaan terhadap hukum sebagai sesuatu yang bermanfaat atau menguntungkan jika hukum tersebut ditaati. Seseorang di sini nantinya akan mempunyai kecenderungan untuk mengadakan penilaian tertentu terhadap hukum mengenai layak atau tidak suatu hukum bagi masyarakat ditinjau dari manfaat dan kerugian yang ditimbulkannya.

Indikator yang keempat adalah pola perilaku seseorang atau masyarakat yang mematuhi peraturan yang berlaku. Indikator ini merupakan indikator yang paling utama karena di dalamnya dapat dilihat apakah suatu peraturan berlaku atau tidak dalam masyarakat. Berlakunya suatu peraturan ditunjukkan oleh perilaku yang ditunjukkan oleh masyarakat sebagai akibat dari kepatuhan terhadap hukum, sehingga seberapa jauh kesadaran hukum dalam masyarakat dapat dilihat dari pola perilaku yang ada.

Berkenaan dengan syarat dan prosedur kesadaran hukum untuk mengupayakan pemahaman masyarakat terhadap hukum yang mengatur tentang berbagai peraturan maka perlu adanya kehendak agar kesadaran hukum bisa berjalan, hal ini sesuai dengan teori yang dikemukakan oleh Soekanto (1977, hal. 468-469) bahwa pengetahuan mengenai hukum, pemahaman tentang hukum, kesadaran tentang kewajiban hukum kita terhadap orang lain, serta pola perilaku terhadap hukum bisa berjalan sebagaimana mestinya dan membangun kesadaran, maka terdapat syarat-syarat prosedur yang harus dilakukan sebagai berikut:

1. Kesadaran hukum harus didasari pengetahuan tentang hukum. jika seseorang tidak mengetahui apa itu hukum, tentu tidak bisa menjalankan hukum sebagaimana mestinya. Masyarakat harus mengetahui bahwa hukum adalah hal yang penting untuk berlindung dari berbagai hal yang menyalahi hukum.

2. Pemahaman hukum. Pemahaman akan hukum sangat penting disebabkan ketika seseorang hanya tahu saja dan tidak paham sepenuhnya, maka akan terjadi salah paham yang mengakibatkan hukum tidak berjalan sebagaimana mestinya. Oleh karena itu pemahaman hukum harus menjadi satu hal yang dimiliki oleh setiap individu.

3. Sikap terhadap peraturan hukum. Ketika seseorang mengetahui apa yang boleh dan tidak boleh dilakukan kepada orang lain, dan sadar bahwa akan ada ganjaran dari setiap hal yang dilakukan, maka secara otomatis mereka akan memiliki kesadaran hukum.

4. Perilaku yang sesuai dengan peraturan. Meskipun seseorang mengetahui dan memahami hukum dengan baik, mengerti kewajiban hukum terhadap orang lain, namun apabila mereka tidak mau menerima hukum tersebut, maka kesdaran hukum tidak akan terwujud dan hukum tidak akan bisa berjalan sebagaimana mestinya. Penerimaan hukum di sini dicerminkan oleh adanya tindakan atau perilaku dalam kehidupan yang sesuai dengan hukum yang berlaku dalam

\section{JURNAL KEWARGANEGARAAN}


masyarakat. Membuat masyarakat bisa menerima hukum memang tidak mudah, akan tetapi mengajarkan secara berkala dapat memberikan efek peneriman hukum yang signifikan dalam masyarakat itu sendiri.

\section{Korupsi dan Lembaga KPK}

Korupsi dan lembaga KPK merupakan dua kata yang tidak asing di Indonesia. Jika mendengar dua nomenklatur tersebut maka bayangan yang muncul dalam pikiran seseorang adalah tindak pidana, hukuman atau kasus pencurian uang Negara oleh pejabat pemerintah. Badjuri (2011, hal. 84) menjelaskan Korupsi bukanlah sesuatu yang baru dalam sejarah peradaban manusia. Fenomena ini telah dikenal dan menjadi bahan diskusi bahkan sejak 2000 tahun yang lalu ketika seorang Perdana Menteri Kerajaan India bernama Kautilya menulis buku berjudul Arthashastra. Demikian pula dengan Dante yang pada tujuh abad silam menulis tentang korupsi (penyuapan) sebagai tindak kejahatan. Bahkan Shakespeare juga menyinggung korupsi sebagai bentuk kejahatan. Korupsi berakibat sangat berbahaya bagi kehidupan manusia, baik aspek kehidupan sosial, politik, birokrasi, ekonomi, dan individu.

Dalam menggambarkan pemikirannya mengenai korupsi, Amin Rais (dalam Hamid \& Sayuti, 1999, hal. 23) menyatakan bahwa "corruption is way of life in Indonesia", yang berarti korupsi telah menjadi pandangan dan jalan kehidupan bangsa Indonesia. Hal ini tentu miris sekali jika ditelaah dengan seksama bahwa korupsi telah menjadi perilaku dalam keseharian masyarakat dan tumbuh menjadi kebiasaan buruk dalam tatanan bernegara Indonesia. Kenyataan ini juga mengindikasikan bahwa belum terbentuknya budaya dan kesadaran hukum yang baik dalam diri para oknum pejabat sebagai pelaksana Negara.

Dalam Soemanto, Sudarto, \& Sudarsana (2014, hal. 81), korupsi adalah realitas tindakan penyimpangan norma sosial dan hukum yang tidak dikehendaki masyarakat dan diancam sanksi oleh negara. Korupsi sebagai bentuk penyalahgunaan kedudukan (jabatan), kekuasaan, kesempatan untuk memenuhi kepentingan diri sendiri dan atau kelompoknya yang melawan kepentingan bersama (masyarakat). Lebih lanjut menurut Yunara (dalam Rais, 2017, hal. 123), masalah korupsi terkait dengan kompleksitas masalah, antara lain, masalah moral/sikap mental, masalah pola hidup, kebutuhan serta kebudayaan dan lingkungan sosial, masalah kebutuhan/tuntutan ekonomi dan kesejahteraan sosial ekonomi, masalah struktur/sistem ekonomi, sistem budaya politik, masalah mekanisme pembangunan dan lemahnya birokrasi atau prosedur administrasi (termasuk sistem pengawasan) di bidang keuangan dan pelayanan publik. Sehingga korupsi berpengaruh negatif terhadap rasa keadilan dan kesetaraan sosial yang menyebabkan perbedaan yang tajam antara kelompok sosial dan individu baik dalam pendapatan, nilai-nilai istimewa, kekuasaan dan potensi lainnya.

Di Indonesia sendiri, dalam rangka memberantas kejahatan korupsi maka dibentuklah suatu lembaga khusus yang membidangi masalah korupsi. Lembaga ini dinamakan Komisi Pemberantasan Korupsi (KPK). KPK adalah lembaga negara yang dibentuk dengan tujuan meningkatkan daya dan hasil guna terhadap upaya pemberantasan tindak pidana korupsi. KPK bersifat independen dan bebas dari pengaruh kekuasaan manapun dalam melaksanakan tugas dan wewenangnya. Komisi ini didirikan berdasarkan pada Undang-Undang Republik Indonesia Nomor 30 Tahun 2002 mengenai Komisi Pemberantasan Tindak Pidana Korupsi. Dalam pelaksanaan tugasnya, KPK berpedoman 
kepada lima asas, yaitu: kepastian hukum, keterbukaan, akuntabilitas, kepentingan umum, dan proporsionalitas. Lahirnya Lembaga KPK juga tidak terlepas dari latar belakang kondisi sistem peradilan yang tidak memadai atas tindak pidana korupsi. Senada dengan hal ini, Al Muhtar (2014, hal. 355) bahwa kemampuan sistem peradilan dipandang tidak memadai lagi untuk melakukan pemberantasan korupsi.

Sebagai salah satu unsur yang sangat penting dalam penegakan hukum di suatu Negara, perang terhadap korupsi adalah hal yang tidak dapat dinihilkan karena korupsi merupakan suatu penyakit dan merusak semua sendi kehidupan berbangsa dan bernegara. Tujuan dari dibentuknya lembaga KPK adalah untuk meningkatkan upaya pemberantasan tindak pidana korupsi yang sudah merajalela di seluruh lapisan pelaksana negara. Perang terhadap korupsi merupakan fokus yang sangat signifikan dalam suatu negara berdasarkan hukum, bahkan bisa dianggap sebagai tolak ukur keberhasilan suatu pemerintahan. Dalam Suyatmiko (2019, hal. 36), saat ini terdapat lebih dari 100 lembaga antikorupsi (ACA) di seluruh dunia, dimana 40 diantaranya berada di wilayah Asia Pasifik (Transparency International, 2019).

Sejak tahun 2002, KPK secara formal menjadi lembaga anti korupsi yang dimiliki Indonesia dan membawa pengaruh besar khususnya dalam memberikan pengetahuan masyarakat mengenai isu, tahapan, dan praktik hukum. Sejak awal tahun didirikannya lembaga KPK telah melakukan penegakan kasus korupsi besar, menangkap lebih dari 1.000 pejabat Negara dengan tingkat keberhasilan lebih dari $75 \%$, pengawasan upaya penegakan hukum dalam kasus korupsi, dan menanamkan semangat integritas di masyarakat (Komisi Pemberantasan Korupsi, 2019).

Opini publik dan rasa keadilan masyarakat sepakat bahwa tindakan korupsi adalah suatu kejahatan kepada Negara dan masyarakat. Hal itu terlihat jika ada salah satu oknum pejabat Negara tersandung masalah dengan KPK, perhatian publik terhadap isu korupsi dan pelaksanaan hukum atas tindakan korupsi oleh oknum pejabat menjadikan perhatian publik meningkat. Sehingga penegakan hukum yang dilakukan Lembaga KPK berimplikasi pada kesempatan masyarakat untuk memperoleh informasi hukum atau pendidikan hukum.

Hal ini dinilai sebagai jalur dan metode alternatif dari pendidikan hukum formal dalam membentuk kesadaran hukum bagi seluruh lapisan masyarakat secara luas dan masif. Kesadaran hukum bagi setiap warga negara membentuk tatanan budaya hukum yang lebih baik. Dalam Nuriyanto (2015, hal. 25) dikatakan bahwa "budaya hukum merupakan unsur yang penting dalam sistem hukum, karena budaya hukum memperlihatkan pemikiran dan kekuatan masyarakat yang menentukan bagaimana hukum tersebut ditaati, dihindari atau disalahgunakan". Jalur dan metode dalam membangun kesadasaran hukum warga negara dapat digali dan dioptimalkan melalui media pantauan terhadap kinerja lembaga KPK, sehingga taraf kesadaran budaya hukum di Indonesia menemukan arah positifnya.

\section{Peranan KPK dalam Pendidikan Hukum Masyarakat}

Pendidikan hukum dari defenisi di atas adalah proses pengalihan, proses transfer atau menyebarkan pengetahuan tentang aturan yang berfungsi untuk mengatur kehidupan masyarakat, dengan tujuan terciptanya perubahan perilaku taat hukum dari masyarakat yang dirancang secara terstruktur, terencana, dan tersistem dengan baik oleh pihak terkait. Dengan kata lain, pendidikan hukum menurut penulis esensinya ialah wadah ataupun alat

\section{JURNAL KEWARGANEGARAAN}


yang digunakan sebagai media penyampaikan tentang nilai, larangan, dan aturan tentang kehidupan bermasyarakat, yang jika ditaati akan berguna dalam menciptakan kehidupan masyarakat yang lebih tenteram, tertib, dan damai.

Lembaga KPK sangat berhubungan dengan proses pemberian pemahaman dan cara kerja hukum dalam masyarakat. Tugas-tugas KPK diantaranya adalah melakukan koordinasi dengan instansi yang berwenang, melakukan pemberantasan tindak pidana korupsi; supervisi terhadap instansi yang berwenang, melakukan pemberantasan tindak pidana korupsi, penyelidikan, penyidikan dan penuntutan terhadap tindak pidana korupsi; melakukan tindakan-tindakan pencegahan tindak pidana korupsi serta melakukan pemantauan (monitoring) terhadap penyelenggaraan pemerintahan negara. Dalam Giddens (2005, hal. 490), disebutkan bahwa dunia modern bergantung pada komunikasi atau interaksi yang berkelanjutan antara orang-orang yang terpisah satu sama lain. Ketergantungan akan hal di luar dirinya menjadi dasar untuk masyarakat mengikuti laju informasi. Begitupun infomasi mengenai Negara dan pemerintahan.

Dalam Natalia (2019, hal. 59), menurut Coronel, "gagasan media massa sebagai pilar keempat demokrasi dengan tugas utama sebagai check and balance terhadap para pemilik jabatan publik didasari premis bahwa jangan sampai suatu kekuasaan melampaui batasannya". Situasi tersebut adalah suatu kewajaran sebagai konsekuensi atas pilihan Negara demokratis, termasuk Indonesia. Oleh karena itu, media massa berubah menjadi media yang memenuhi kebutuhan informasi warga negara atas penyelenggaraan Negara oleh pemerintah. Maka kegiatan penyampaian informasi atau pelaporan hasil investigasi adalah salah satu sarana edukasi pengetahuan hukum masyakarat di segala lapisan.

Dengan tingkat kepercayaan kinerja lembaga KPK yang baik dari masyarakat, menjadikannya dasar bahwa aktivitas penegakan Hukum (pemberantasan korupsi) yang dilakukan oleh KPK adalah layak sebagai acuan masyarakat untuk mempelajari hukum di luar pendidikan formal. Berita-berita yang dipublikasi oleh media massa, konferensi pers KPK atau keterangan dari juru bicara KPK kerap dijadikan referensi oleh masyarakat dalam memahami proses penegakan hukum dari tahapan seseorang menjadi terduga, tersangka atau terpidana dalam sebuah kasus pidana korupsi.

Senada dengan hal tersebut, Widhiyaastuti (2018, hal. 23), menyatakan bahwa "dalam upaya membangun kesadaran hukum seseorang, edukasi atau pendidikan merupakan salah satu jalur yang dapat dipergunakan. Dengan pelaksanaan hukum yang baik diharapkan dapat dijadikan media pembangun karakter paham dan taat akan hukum sehingga timbul kemauan untuk melaksanakan hukum dan menjadi bagian dari hukum itu sendiri". Maka dari itu Pendidikan Hukum dalam PKn dapat diartikan sebagai program pengarahan untuk membina siswa menjadi warga negara yang memiliki kesadaran hukum yang tinggi, menyadari akan hak dan kewajibannya dan memiliki kepatuhan terhadap hukum, sehingga mampu mempertahankan nilai-nilai yang dianggap baik oleh masyarakat.

Dampak dari pendidikan hukum bagi masyarakat dari pemberitaan media massa mengenai hasil kinerja lembaga KPK sekurang-kurangnya dapat dibagi menjadi dua menurut Stapenhurs (dalam Natalia, 2019, hal. 60): pertama, memberikan dampak kasat mata (tangible) mengenai korupsi kepada masyarakat. Bentuk yang paling spektakuler misalnya ketika pemimpin korup dapat dimakzulkan, dituntut atau dipaksa untuk mengundurkan diri setelah kejahatan mereka dipertontonkan kepada publik lewat media. Kedua, memberikan dampak tidak kasat mata (intangible) misalnya dengan ikut 
menyajikan informasi dan pemahaman kepada masyarakat mengenai tata kelola pemerintahan yang baik dan transparan, peningkatan kualitas debat publik dan mendorong akuntabilitas antara politisi dengan lembaga-lembaga publik sebagai hasil pemberitaan media massa yang kritis dan independen.

Dari kutipan di atas apabila ditarik kesimpulan lebih sederhana lagi mengenai dampak pendidikan hukum bagi kesadaran hukum masyarakat, yaitu; pada bagian pertama memberikan gambaran rasa takut dan malu manakala seseorang yang melanggar hukum dipertontonkan, ditangkap, diadili kemudian dipenjara oleh pihak yang berwajib. Ranah ini dapat dikaitkan penanaman atau pembiasaan standar moral (sikap) yang dianggap baik di masyarakat. Kesadaran mendasar ini penting dimiliki masyarakat mengingat bahwa kesadaran hukum tidak berbanding lurus dengan pengetahuan hukum warga negara. Selanjutnya bagian kedua, berbeda dengan bagian pertama yang menitikberatkan pada dampak langsung, bagian kedua masuk kedalam ranah penanaman kognisi atau pengetahuan kepada masyarakat. Media massa mengedukasi masyarakat berkaitan tata aturan hukum, mengkaji korupsi dengan berbagai pihak terkait, mengkaji data-hukum tentang proses pemberantasan korupsi dan hal-hal lain yang bertujuan memberikan informasi kritis mengenai hukum dan pemberantasan korupsi.

Peluang keterkaitan antara KPK dengan pendidikan hukum secara jelas harus dikuatkan dalam salah satu bidang KPK yakni melalui bidang pencegahan. Bidang pencegahan KPK memiliki fungsi dasar memberikan pendidikan anti korupsi, sosialisasi pemberantasan tindak pidana korupsi dan kampanye antikorupsi. Fungsi-fungsi dasar tersebut harus terus didorong untuk berinovasi dan berkreasi dalam menyusun program yang bersentuhan langsung dengan masyarakat dan sekaligus berdampak pada peningkatan pemahaman dan kesadaran hukum seluruh lapisan masyarakat.

\section{Kinerja KPK Sebagai Sumber Pembelajaran Pendidikan Hukum}

KPK, selain sebagai lembaga hukum yang membidangi masalah yang berkaitan dengan tindak korupsi, dalam praktiknya memiliki peranan lain yakni sebagai media belajar pendidikan hukum, baik di sekolah maupun dalam tatanan masyarakat. Dalam pendidikan hukum di sekolah atau kampus, materi ini menjadi pembahasan yang panjang, diantaranya mengenai pelaksanaan tugas lembaga KPK, perspektif hukum yang digunakan, tahapan penegakan hukum, pasal-pasal yang digunakan merupakan hal-hal yang biasa dijadikan kajian dalam diskusi di ruang kelas, sehingga peserta didik dapat merasakan pemahaman nyata dari teori hukum yang diajarkan guru. Dalam Rahardjo (2010, hal. 66), Jika fungsi PKn sebagai pendidikan nilai berhasil, maka hal tersebut juga akan menunjang fungsi PKn sebagai Pendidikan Hukum, karena salah satu paradigma hukum adalah hukum dianggap sebagai perwujudan nilai-nilai yang mengandung arti bahwa kehadirannya adalah untuk memajukan nilai-nilai yang dijunjung tinggi oleh masyarakat. Hal tersebut dikuatkan dalam Mushafi \& Marzuki (2018, hal. 56), suatu aturan atau hukum yang sudah memenuhi harapan suatu masyarakat serta mendapat dukungan, belum tentu dapat berjalan dengan baik bila tidak didukung oleh aparat pelaksana yang rumit terhadap pelaksanaan hukum.

Tingkat kepercayaan terhadap kinerja kepada lembaga KPK yang baik dari masyarakat akan memberikan ruang bagi guru untuk menguatkan kesadaran hukum pada peserta didik. Seperti yang dijelaskan oleh Al Muhtar (2014, hal. 360), pendidikan hukum tidak terbatas pada mempersiapkan tenaga professional, akan tetapi juga bertujuan untuk 
mencerdaskan dan membina kesadaran hukum warga negara. Dalam Utomo (2018, hal. 17), membangun masyarakat yang sadar hukum merupakan hal penting yang diharapkan akan membentuk dan menjadikan masyarakat menjunjung tinggi institusi/aturan sebagai pemenuhan kebutuhan dan pengharapan akan ketaatan dan ketertiban.

Praktik penegakan hukum yang berlangsung dalam lembaga KPK harus diinternalisasi oleh pengajar hukum untuk membangun sikap sadar hukum dari peserta didiknya. Pendidik hukum mendorong peserta didik untuk dapat mengklasifikasi efek ketika seorang warga negara tidak tunduk terhadap hukum. Nilai-nilai tersebut kuatkan ke dalam lingkungan sekolah, keluarga dan masyarakat melalui berbagai program yang dilakukan secara rutin, normatif, sehingga menjadi nilai yang membudaya dalam masyarakat sehingga output yang diharapkan adalah individu yang berperilaku antikorupsi atau secara umum kemiliki kecerdasan hukum. Dalam Handayani \& Halili (2016, hal. 15) sebagai daya dorong KPK berupaya untuk menstimulus dan memberdayakan institusi yang telah ada untuk bekerjasama dalam pemberantasan tindak pidana korupsi, termasuk melalui upaya pendidikan.

Selain KPK dapat dijadikan sumber belajar pada tataran pendidikan, KPK juga memiliki pengaruh besar pada masyarakat umum. Proses penegakan hukum para koruptor, dan kerja-kerja lainnya dari lembaga KPK yang disebarluaskan melalui media massa, televisi, koran, maupun media online berperan besar terhadap pendidikan hukum dan pemahaman hukum masyarakat. Berbeda dengan sistem pendidikan yang dilaksanakan di persekolahan, pendidikan hukum dalam masyarakat lebih bersifat tradisional. Pendidikan hukum dalam masyarakat lebih menekankan pada konsep pemberian contoh dan pemahaman secara langsung sehingga masyarakat melihat dengan nyata bagaimana seharusnya hukum diterapkan. Dalam prosesnya, pelaksaan pembelajaran hukum dalam masyarakat tidak akan terlaksana tanpa adanya dukungan berbagai pihak. Dalam hal ini adanya pemerintah sebagai role model, media, sebagai perantara pelaksanaan dan intensitas pembelajaran.

Hal ini sesuai dengan konsep Giddens tentang sentralitas waktu dan ruang pembelajaran. Menurut Giddens (dalam Nanda \& Mudzakkir, 2013, hal. 6), dijelaskan, pengetahuan siswa tidak hanya bersumber pada guru. Di era modern ini informasi dapat diperolah dari kemajuan teknologi informasi, seperti internet. Lebih lanjut dalam Jamun (2018, hal. 49), komunikasi sebagai media pendidikan dilakukan dengan menggunakan media-media komunikasi seperti telepon, komputer, internet, e-mail dan lain sebagainya. Interaksi antar guru dan siswa tidak hanya dilakukan melalui hubungan tatap muka dan juga dilakukan dengan menggunakan media-media tersebut.

Maka pelibatan teknologi digital dalam pendidikan berdampak pada hadir ruang dan cara belajar baru yang implikasi meningkatnya motivasi belajar siswa. Dalam Muhasim (2017, hal. 74), sarana media pembelajaran digital yang bermutu dapat meningkatkan kualitas belajar siswa dan meningkatkan motivasi dalam kegiatan belajar. Hal ini juga memberi peluang untuk belajar banyak dari berbagai media komunikasi digital yang beroperasi di luar konteks sekolah. Dalam contoh fenomena ini, masyarakat akan cukup tertarik dengan informasi-informasi yang disampaikan oleh KPK melalui Komisioner ataupun juru bicara. Efeknya adalah masyarakat mendapat pengetahuan sebagai dasar pemahaman hukum dalam bernegara.

Menurut laporan yang dirilis oleh Lembaga Survei Indonesia (2019) tentang Tingkat Kepercayaan terhadap institusi Publik, kepercayaan publik terhadap KPK 
mencapai 84\%. Hal ini tidak lepas dari cara pandang humas KPK dalam melihat peran informasi publik, sebagai bentuk pertanggungjawaban dari pekerjaan yang dilakukan. KPK bertanggung jawab pada publik. Jadi bukan sosialisasi keberhasilan, tapi lebih dari itu, (yakni) mempertanggungjawabkan uang yang diberikan kepada masyarakat. Dengan demikian kinerja dari komisioner dan juru bicara KPK dapat mendapat perhatian lebih dari pelaksanaan tugasnya yang kemudian berimplikasi pada pengaruhnya sebagai sumber belajar pendidikan hukum di masyarakat.

Jika ditinjau dari perspektif komunikasi publik, peran komisioner dan Jubir KPK saat menyampaikan informasi di media massa menjalankan fungsi memberikan penerangan. Penerangan dapat berhasil dan memberikan pengetahuan kepada masyarakat manakala komisioner dan Jubir KPK menguasai informasi berbagai hal yang berkaitan dengan penguasaan masalah. Dalam Penyampaian informasi, idealnya orang yang menyampaikan harus menguasai masalah dan didukung oleh data serta fakta sebagai bukti. Dengan demikian, sebelum tampil dan menyampaikan informasi kepada public, komisioner dan Jubir KPK harus mengetahui secara lengkap konteks permasalahan yang terjadi berkaitan dengan lembaganya, dan harus bisa meyakinkan mana informasi yang pantas disajikan menjadi informasi publik dan mana yang tidak boleh disampaikan. Ketentuan mengenai penyampaian informasi publik itu harus dikaitkan dengan aturanaturan yang ada.

Hal ini akhirnya menimbulkan reaksi masyarakat umum, karena adanya jalinan relasi serta interaksi antara organisasi dengan berbagai komponen stakeholders. Dalam setiap interaksi itu masyarakat memperoleh informasi dan pendidikan hukum yang jelas dan akurat tentang hal yang tengah diinformasikan. Keingintahuan masyarakat semakin meningkat apabila tindakan ataupun perlakukan yang diterima oleh tersangka tidak sesuai dengan rasa keadilan dalam masyarakat. Hal ini membangkitkan nalar kritis tentang konsep keadialan.

Keterbukaan KPK untuk kerjasama dengan instansi lain dan masyarakat luas sangat sejalan dengan prinsip penguatan pemahaman hukum demi membentuk warga Negara yang sadar hukum. Dalam Handayani \& Halili (2016, hal. 5) disebutkan bahwa KPK Membuka ruang keterlibatan partisipasi masyarakat dalam upaya untuk mempercepat penyebaran semangat antikorupsi, yang selanjutnya mengajak masyarakat untuk terlibat aktif, KPK mengadakan workhsop di berbagai daerah.

\section{SIMPULAN}

Pendidikan hukum dalam masyarakat merupakan upaya yang dilakukan untuk menimbulkan kesadaran hukum. Dalam membangun kesadaran hukum, pendidikan hukum diberikan pada seluruh warga negara yang ada, baik kalangan pelajar, mahasiswa maupun masyarakat secara umum. Oleh karena itu, berdasarkan objek penerimanya, bentuk pendidikan hukum yang diteliti oleh penulis secara umum diklasifikasikan menjadi dua jenis, yaitu pendidikan kewarganegaraan yang disampaikan untuk kalangan peserta didik maupun mahasiswa, dan pendidikan hukum secara umum yang diberikan untuk masyarakat.

Oleh karena sifat keumuman pendidikan hukum bagi masyarakat ini, maka penulis menyimpulkan bahwa masyarakat perlu memiliki pandangan khusus yang terfokus sebagai role model kiblat hukum mereka. Dalam hal ini KPK memenuhi seluruh harapan 
tersebut. Sebagai lembaga hukum independen, KPK tidak hanya berfungsi sebagai pemberantas tindak pidana korupsi saja, akan tetapi juga melakukan pencegahan tindak pidana korupsi serta pemantauan (monitoring) terhadap penyelenggaraan pemerintahan Negara. Penyampaian kinerja KPK untuk masyarakat luas disalurkan melalui berbagai media massa, oleh karena itu dampak dari pendidikan hukum yang diperoleh masyarakat benar-benar membekas dan memberi pengalaman memantau pelaksanaan hukum nasional secara langsung.

\section{UCAPAN TERIMA KASIH}

Ucapan terima kasih kami ucapkan kepada semua pihak yang telah membantu penyelesaian karya ilmiah ini. Semoga Allah SWT membalas dengan kebaikan yang melimpah. Aamiin ya Robbal 'Alamin.

\section{DAFTAR PUSTAKA}

Abdullah, J. (2015). Refleksi dan Relevansi Pemikiran Filsafat Hukum Bagi Pengembangan Ilmu Hukum. YUDISIA : Jurnal Pemikiran Hukum dan Hukum Islam, 6(1), 181-199. https://doi.org/10.21043/YUDISIA.V6I1.1498

Ahmad, I. (2018). Rencana dan Strategi Peningkatan Kesadaran Hukum Masyarakat. Gorontalo Law Review, 1(1), 15-24. https://doi.org/10.32662/golrev.v1i1.94

Al Muhtar, S. (2014). Filsafat Hukum Kajian Filsafati Kearah Memperkuat Konsepsi Sistem Hukum Pancasila. Bandung: Gelar Pustaka Mandiri.

Badjuri, A. (2011). Peranan Komisi Pemberantasan Korupsi (KPK) sebagai Lembaga Anti Korupsi di Indonesia. Jurnal Bisnis dan Ekonomi, 18(1), 84-96.

Erwin, M. (2011). Filsafat Hukum. Jakarta: PT. Raja Grafindo Persada.

Hamid, E. S., \& Sayuti, M. (Ed.). (1999). Menyingkap Korupsi, Kolusi,dan Nepotisme di Indonesia. Yogyakarta: Aditya Media.

Handayani, Q., \& Halili. (2016). Peranan Komisi Pemberantasan Korupsi (KPK) dalam Mendesain Kelembagaan Pendidikan Antikorupsi. Jurnal Pendidikan Kewarganegaraan dan Hukum, 1-14. Diambil dari https://adoc.pub/peranankomisi-pemberantasan-korupsi-kpk-dalam-mendesain-kel.html

Jamun, Y. M. (2018). Dampak Teknologi Terhadap Pendidikan. Jurnal Pendidikan dan Kebudayaan Missio, 10(10), 48-52. Diambil dari http://jurnal.unikastpaulus.ac.id/index.php/jpkm/article/view/54

Komisi Pemberantasan Korupsi. (2019). Laporan Tahunan KPK tahun 2019. Diambil dari https://www.kpk.go.id/id/publikasi/laporan-tahunan/1702-laporan-tahunankpk-2019

Lembaga Survei Indonesia. (2019). Efek Kinerja Pemberantasan Korupsi terhadap Dukungan pada Jokowi. Diambil dari http://www.lsi.or.id/riset/444/rilis-temuansurvei-nasional-290819 
Muhasim, M. (2017). Pengaruh Tehnologi Digital terhadap Motivasi Belajar Peserta Didik. PALAPA, 5(2), 53-77. https://doi.org/10.36088/palapa.v5i2.46

Mushafi, M., \& Marzuki, I. (2018). Persinggungan Hukum dengan Masyarakat dalam Kajian Sosiologi Hukum. Jurnal Cakrawala Hukum, 9(1), 50-58. https://doi.org/10.26905/idjch.v9i1.2168

Nanda, R. W., \& Mudzakkir, M. (2013). Transformation Sistem Pendidikan Full Day School di Era Globalisasi. Paradigma, 1(3), 1-10.

Nasution, A. R. (2016). Urgensi Pendidikan Kewarganegaraan sebagai Pendidikan Karakter Bangsa Indonesia melalui Demokrasi, HAM dan Masyarakat Madani. JUPIIS: Jurnal Ilmu Pendidikan dan Sosial, 8(2), 201-212. https://doi.org/10.24114/jupiis.v8i2.5167

Natalia, D. L. (2019). Media Massa dan Pemberitaan Pemberantasan Korupsi di Indonesia. Jurnal Antikorupsi Integritas, 5(2), 57-73. https://doi.org/10.32697/INTEGRITAS.V5I2.472

Nuriyanto. (2015). Membangun Budaya Hukum Pelayanan Publik untuk Mewujudkan Kesejahteraan Rakyat. INTEGRITAS, 1(1), 15-36. https://doi.org/10.32697/integritas.v1i1.112

Purba, I. P. M. H. (2017). Penguatan Budaya Hukum Masyarakat untuk Menghasilkan Mewarganegaraan Transformatif. Jurnal Civics: Media Kajian Kewarganegaraan, 14(2), 146-153.

Rahardjo, S. (2010). Sosiologi Hukum. Yogyakarta: Genta Publishing.

Rais, M. (2017). Nilai Keadilan Putusan Hakim Pada Perkara Tindak Pidana Korupsi. Al Daulah: Jurnal Hukum Pidana dan Ketatanegaraan, 6(1), 121-144. https://doi.org/10.24252/ad.v6i1.4870

Saifullah. (2007). Refleksi Sosiologi Hukum. Bandung: Refika Aditama.

Salman, O. (1993). Kesadaran Hukum Masyarakat Terhadap Hukum Waris. Bandung: Penerbit Alumni.

Soekanto, S. (1977). Kesadaran Hukum dan Kepatuhan Hukum. Jurnal Hukum \& Pembangunan, 7(6), 462-170. https://doi.org/10.21143/jhp.vol7.no6.742

Soekanto, S. (1982). Kesadaran Hukum dan Kepatuhan Hukum. Jakarta: Rajawali Pers.

Soemanto, R., Sudarto, \& Sudarsana. (2014). Pemahaman Masyarakat Tentang Korupsi. Yustisia Jurnal Hukum, 3(1), 80-88. https://doi.org/10.20961/yustisia.v3i1.10124

Subiharta. (2015). Moralitas Hukum dalam Hukum Praktis Sebagai Keutamaan Hukum. Jurnal Hukum dan Peradilan, 4(3), 385-398. https://doi.org/10.25216/jhp.4.3.2015.385-398

Suparman, H. A. (2016). Penegakan Hukum Terhadap Penyelenggara Pelayanan Publik. Jurnal Wawasan Yuridika, 31(2), 177-182. https://doi.org/10.25072/JWY.V31I2.85

Suyatmiko, W. H., \& Nicola, A. (2019). Menakar Lembaga Antikorupsi: Studi Peninjauan Kinerja Komisi Pemberantasan Korupsi. Jurnal Antikorupsi Integritas, 5(2), 35-56. https://doi.org/10.32697/INTEGRITAS.V5I2.465

\section{JURNAL KEWARGANEGARAAN}


Tauratiya. (2018). Faktor Masyarakat Timbulnya Kepatuhan Masyarakat Terhadap Hukum (Legas Obedience). Asy Syar'iyyah: Jurnal Ilmu Syariah dan Perbankan Islam $\quad-, \quad 3(2), \quad 63-81 . \quad$ Diambil dari https:/jurnal.lp2msasbabel.ac.id/index.php/asy/article/view/1169

Transparency International. (2019). Corruption Perceptions Index 2019. Diambil dari www.transparency.org/cpi

Usman, A. H. (2014). Kesadaran Hukum Masyarakat Dan Pemerintah Sebagai Faktor Tegaknya Negara Hukum Di Indonesia. Jurnal Wawasan Yuridika, 30(1), $26-53$. https://doi.org/10.25072/jwy.v30i1.74

Utomo, P. (2018). Membangun Kesadaran Hukum Masyarakat Menuju Green City. Nurani Hukum, 1(1), 11-20.

Undang-Undang Republik Indonesia Nomor 30 Tahun 2002 Tentang Komisi Pemberantasan Tindak Pidana Korupsi

Wahab, A. A., \& Sapriya. (2011). Teori \& Landasan Pendidikan Kewarganeraan. Bandung: Alfabeta.

Widhiyaastuti, I. G. A. A. D., \& Ariawan, I. G. K. (2018). Meningkatkan Kesadaran Generasi Muda Untuk Berperilaku Anti Korupsi Melalui Pendidikan Anti Korupsi. Acta Comitas, 3(1), 17-25. https://doi.org/10.24843/ac.2018.v03.i01.p02

Wignjosoebroto, S. (2013). Hukum dalam Masyarakat. Yogyakarta: Graha Ilmu. 
